\title{
Areas for Research and Investigation in the College Library Field
}

Miss Cole is editor, Library Literature, H.W.Wilson Company.

This is a report of a quick survey made for the College Libraries Section of the A.C.R.L. in December 1949. Sixty-three librarians from 29 states responded to the request for information. Several of these librarians replied at some length and suggested a number of problems for investigation. In some cases the results of special staff meetings on this topic were reported, with suggestions being contributed by members of the professional staff as well as by the chief librarian. The general tone of the replies indicated not only a spirit of goodwill toward the current project but also a great depth of interest in the topic being investigated.

One hundred and thirty-nine problems were suggested by the respondents. The following categories for classifying the data were developed:

I. General administrative problems

2. Public relations and extension services

3. Personnel

4. Finance

5. Relations with faculty and curriculum

6. Selection and acquisition of printed materials

7. Problems of nonprint materials

8. Cataloging and classification

9. Circulation work, including interlibrary loan

10. Reference and bibliography

II. Instruction in the use of the library

12. Evaluation of collections and services

13. Buildings and equipment

14. Cooperation with other institutions

I5. Reading problems

Numerically, the problems relating to the general administration of the college library seem to be of most importance to college li-

1 Based on a paper presented at meeting of the College Libraries Section, A.C.R.L., Chicago, Jan. 27, I950. brarians. Other problems mentioned frequently are those of nonprint materials, finance, instruction in the use of the library, personnel and buildings. Problems mentioned least frequently are: reading, relations with faculty and curriculum, and reference and bibliography. Table I shows the rank order of returns:

Are there any regional differences in the topics suggested by college librarians? In order to answer this question, the returns were divided into four regional groups, namely, East, South, Midwest, and West. The fields in which eastern college librarians expressed greatest interest are: general -administrative problems, finance, problems of nonprint materials, instruction in the use of the library, buildings and equipment. In the South, instruction in the use of the library was the field mentioned most frequently; relations with faculty and curriculum, general administrative problems, selection and acquisition of printed materials, and evaluation of collections and services are included in the most frequently mentioned fields. Midwestern librarians found general administrative problems and problems of nonprint materials most important, with finance, buildings, cataloging and instruction in the use of the library next in importance. In the West, finance seemed to be the field of greatest interest, with problems of nonprint materials tieing for second place.

What are the research interests of specialized institutions, as opposed to the general trend? Not enough data were available from Catholic institutions to provide any statement. Research interests of teachers colleges as expressed by the returns center very definitely in the following areas: instruction in the use of the library, buildings and equipment, personnel, and problems of nonprint materials. Negro institutions express almost their entire interest in the fields of circulation work and instruction in the use of the library. Interests of the technical colleges seem to be 
Table I

\begin{tabular}{l|c}
\hline \hline \multicolumn{1}{c|}{ Subject Field } & $\begin{array}{c}\text { Rank } \\
\text { Order }\end{array}$ \\
\hline Administration & I \\
Nonprint materials & 2 \\
Finance & 3 \\
Instruction & 3 \\
Personnel & 5 \\
Buildings & 5 \\
Evaluation & 7 \\
Cataloging & 8 \\
Selection of printed materials & 9 \\
Public relations & I0 \\
Circulation & I0 \\
Cooperation & I0 \\
Reading problems & I0 \\
Relations with faculty and curriculum & I2 \\
Reference and bibliography & I2 \\
\hline
\end{tabular}

distributed fairly evenly over the various categories, with only slight concentration of interest in evaluation of collections and services.

No evaluation of the facts concerning the regional differences in research topics or the research interests of specialized institutions can be attempted. They are presented merely as indications of possible trends.

Before turning to an examination of the specific questions which have been raised in each of the subject areas it is necessary to note the fact that there was no attempt to define the terms "research" or "investigation" for the respondents. It is readily apparent that the returns represent several different levels of endeavor, ranging from the quick service study of value to one institution to the formalized project which makes an original contribution to professional literature.

\section{General Administrative Problems}

A number of somewhat varied problems fell within this category. Several respondents mentioned the problems of library statistics. Particular mention was made of the need for a code which would enable the collection of uniform and comparable data. In this connection was mentioned the need for ascertaining the potential usefulness of types of statistical data which are not now being collected. Other studies which might be undertaken include: problems in the administration of small staffs, effectiveness of the library committee as an administrative tool, further investigation of the whole student assistant problem. Two or three librarians raised the question of closed vs. open stacks, particularly as it relates to the mutilation of library materials. A study ot divisional vs. functional arrangement of college libraries seems to offer a challenge, as does the question of the optimum size of the library for undergraduate use. Finally, there is the forthright request for "an honest report on whether 'Friends of the Library' groups have generally proved to be more troublesome than rewarding."

\section{Public Relations and Extension Services}

The question raised most frequently in this area concerns the participation of the college library in radio and television programs sponsored by the college. Other respondents wish to know how far the college library should go in sponsoring or materially aiding adult education programs or other types of extension work.

\section{Personnel}

Status of college librarians was the problem most frequently mentioned in this category. Several librarians asked for new studies which would compare library staffs with teaching staffs with respect to salary, rank, privileges, tenure, and institutional responsibilities, including committee work. Other problems which were suggested include: standards for the selection of college library personnel, and induction techniques.

\section{Finance}

Financial problems are several, but the budget seems to be one of the most pressing. Apparently college librarians have never solved to their satisfaction the problem of the objective distribution of the book funds among the academic departments. Another fundamental problem is raised by a librarian of a landgrant college: "Standards of financial support for college libraries differ remarkably from the standards of financial support for university libraries. Should this be, and if so, why? Why has it been assumed in the past that university libraries need more money on a basis oi per student enrolled than college libraries?"

Cost studies of processes are indicated: for maintaining open or closed reserves, for ordering books and other material, for discarding books, for handling gifts. Several persons expressed interest in accounting and bookkeeping practices and in the relation of the library to the college fiscal office. New cost studies in cataloging, similar to those made before the 
war by Miller, Knapp and Rider seem to be needed. A liberal arts college librarian outlines a long-range project: "Subject: Projection of costs in salaries for personnel and in equipment over a certain period of years for library collections of a certain size and rate of growth. In other words-how much does the cost of care and administration of a collection increase as the collection of books and other materials increases? A mathematical equation or group of equations which could be applied to libraries of different sizes or of different rates of growth would be of enormous value, if the figures could be worked out."

\section{Relations with Faculty and Curriculum}

One librarian has asked for techniques for faculty indoctrination. Another wishes to know how to motivate the faculty to assume its full responsibility for book selection. These are typical of the problems which were raised in this category.

\section{Selection and Acquisition of Printed Materials}

An investigation of publishers' and jobbers' discounts to college libraries has been suggested. Further aids to the selection of periodicals and documents for college libraries appear to be needed. One person noted the need for a revision of Kathryn N. Miller's Selection of United States Government Documents for the Liberal Arts College. Another librarian recommends further investigation of techniques for the exchange of duplicates.

\section{Problems of Nonprint Materials}

The problems classified within this category fall into two groups. The first of these deals with audio-visual aids: the library's responsibility for administering them, problems of acquisition, cataloging, housing, and use of such materials. The second group of problems relate to the implications of photographic techniques for college libraries. College librarians are interested in knowing what specific effect the use of microfilm and microcards will have on future planning in terms of space, staff, finance, binding, and cataloging.

\section{Cataloging and Classification}

The question, "The card catalog-finding list or reference tool?" is a very pertinent one to one college librarian who, as he phrases it, is confronted "with the possibility of having to catalog a 130,000 volume reference library in the face of high costs." Interest is expressed in the problem of quick and economical processing of materials of temporary interest. Reducing the cost of cataloging seems to be of as much interest to college librarians as to their colleagues in other branches of library service. Several needed publications were mentioned: a subject heading list for undergraduate colleges, a cataloging code for the small college library, and a list of reference books useful to college library catalogers.

\section{Circulation Work}

Methods of reducing costs of interlibrary loans, a study of college library charging systems, and studies of the control of overdue books are mentioned in this area.

\section{Reference and Bibliography}

One respondent thinks that a study of readers' advisory work in colleges would be valuable. Another raises what appears to be a fundamental question, "Where does teaching leave off and the giving of assistance to students begin?" implying the need for a more searching definition of college reference work. A directory of the special collections in college, university and research libraries was suggested.

\section{Instruction in the Use of the Library}

Great interest has been shown in this aspect of college library work. Among the responses may be found these requests: ( 1 ) accounts of successful full-length courses of library instruction for undergraduates; (2) the development of new objective tests of library knowledge for use with entering freshmen; (3) study of library instruction for upper classmen; (4) development of effective teaching materials, including audio-visual aids; (5) evaluation of various types of instruction employed in teaching undergraduates the use of the library.

\section{Evaluation of Collections and Services}

Discarding of books, that process which has been called "book selection in reverse," is of great concern to college librarians. Several librarians are seeking objective criteria for use in this connection. As a teachers college librarian expressed it: "We are all jam packed with material whether we have large libraries or small ones, and all of us are faced with the 
problems of what to keep and what to throw away. Too many librarians are attempting to make their libraries exhaustive on too many subjects. So someone should make a study of what the college library should do about discarding, and formulate some sort of yardstick as to what the library should collect and keep."

Two librarians mentioned evaluation of standard lists of books for colleges, while another is interested in finding methods of determining faculty and student opinion of library practices and services.

\section{Buildings and Equipment}

The problem of whether to build a new building or to remodel the old one is far from a theoretical matter, if we judge from the responses of college librarians. Others are interested in knowing how the modular type of building is meeting the needs of colleges. A teachers college librarian indicates a widespread need, for “. . . standards for college library buildings capable of being administered by two librarians plus student assistants. I believe there are more college libraries in this class than any other, yet the plans discussed in our literature are always for much larger buildings."

Three librarians expressed interest in knowing what labor-saving devices can be effectively used in the college library.

\section{Cooperation with Other Institutions}

The title of this category describes the problems raised therein. Librarians are inquiring if cooperation is feasible on a regional basis, either in terms of cooperative processing or in specialization by subjects.

\section{Reading Problems}

The chief concern expressed was for the extracurricular reading of students-how to find out what it is, how to enrich and extend it.

The request for information upon which this study is based included two questions: (I) What problems in the college library field need to be investigated; (2) Where and by whom should this work be done? Although the respondents were both articulate and precise in answering the first question, answers to the second were not nearly so satisfactory. Only 28 of the 139 problems provided an indication of where and how the work should be done. Most of the librarians indicated either an A.C.R.L. committee or librarians in individual institutions as the agencies or persons best fitted for handling these projects. In only four cases was it indicated that the research might be done as a dissertation, although it is apparent that many of these problems are suitable research topics for students working for the A.M., M.S. and Ph.D. degrees in library schools.

No systematic check of the above problems was made in order to ascertain if they had already been investigated; however, it was possible to examine the data compiled by Maurice F. Tauber in a paper which appears elsewhere in this issue. The study by Elizabeth F. Kientzle ${ }^{2}$ would seem to meet the need of the librarian interested in the effectiveness of the library committee. To the several college librarians who expressed concern over the status of college library staffs the thesis of Frank A. Lundy, "Faculty Rank of Professional Librarians,"3 should be helpful. The topic of accounting and bookkeeping practices in colleges was studied by Robert Maxwell Trent in 1939. ${ }^{4}$ The suggestion that an evaluation of the North Central check list be evaluated has been approached in the thesis of Eileen M. Thornton.

To draw valid conclusions from a casual study such as this has been would be a hazardous undertaking. One can be sure, however, that college librarians are able to look at their work objectively, that they take a rational view of their limitations, and that they raise substantial and defensible problems which are drawn from the very heart and center of college librarianship. Only one serious omission is evident. In no case did a college librarian indicate that a survey of his institution ought to be made, or that its history should be written, yet it is generally recognized that surveys and historical studies have an important place in college library literature.

One of the respondents stated something like this: "Every aspect and operation of college libraries is in need of constant scrutiny and evaluation." Our brief investigation tends to substantiate that this is indeed so.

"Study of Administrator and Library Committee Relationships in College and University Libraries." A.M., Denver, I948.

3 M. L.S. California, I948.

4 "Financial Records in College Libraries." M.S., Columbia, 1939.

5 "North Central Association Reference Check-List; Some Experiments in Its Application." A.M., Chicago, I 945 . 